\title{
Different kinds of research shoppers, different shoppers, different
cognitive-affective consequences
}

\section{Diferentes tipos de consumidores research shopper, diferentes consecuencias cognitivo-afectivas}

\author{
Nuria Viejo-Fernández, María José Sanzo-Pérez and \\ Rodolfo Vázquez-Casielles \\ Administración de Empresas, Universidad de Oviedo, Oviedo, Spain
}

\begin{abstract}
Purpose - Customer journey is more omnichannel than ever. Currently, one of the most influential omnichannel behaviors is research shopping in its two predominant forms: webrooming and showrooming. The purpose of this study is to determine the possible moderating effect of each of these behaviors from a cognitive-affective perspective.
\end{abstract}

Design/methodology/approach - The proposed theoretical framework was applied to a sample of 636 mobile phone users.

Findings - The results indicated that research shopping moderated the intensity of the relationship between emotions and perceived value and between emotions and satisfaction. The analysis of the moderating effect of each concrete type of research shopping behavior indicated that negative emotions had a more intense negative effect on perceived value and satisfaction in the case of webrooming than in the case of showrooming.

Originality/value - This study focused on determining the possible moderating effect of research shopping vs one-stop shopping and webrooming vs showrooming on the intensity of the relationship between emotions, perceived value and satisfaction, considering determining factors of customer engagement to retailers (Han and Jeong, 2013). To achieve this objective, the authors performed a quantitative research in the Spanish market, choosing mobile phones as a reference product. The results will contribute to the current state of omnichannel retailing research by the analysis - through a cognitive-affective approach - of the consequences that research shopping and each of its two basic types (webrooming and showrooming) have on retailers.

Keywords Perceived value, Satisfaction, Emotions, Showrooming, Webrooming,

Research shopping

Paper type Research paper

(C) Nuria Viejo-Fernández, María José Sanzo-Pérez and Rodolfo Vázquez-Casielles. Published in Spanish Journal of Marketing - ESIC. Published by Emerald Publishing Limited. This article is published under the Creative Commons Attribution (CC BY 4.0) licence. Anyone may reproduce, distribute, translate and create derivative works of this article (for both commercial and noncommercial purposes), subject to full attribution to the original publication and authors. The full terms of this licence may be seen at http://creativecommons.org/licences/by/4.0/legalcode

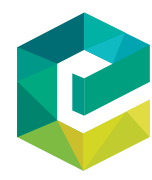

Received 13 September 2018 Accepted 14 December 2018
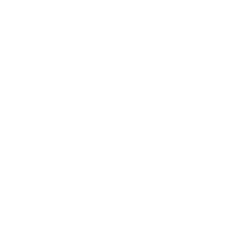


\section{Resumen}

Objetivo - El proceso de compra de los clientes es más omnicanal que nunca. En la actualidad, uno de los comportamientos de compra omnicanal más influyentes es el denominado research shopping en sus dos formas predominantes: el webrooming y el showrooming. El objetivo principal de este estudio es determinar el posible efecto moderador de cada uno de estos comportamientos desde una perspectiva cognitivo-afectiva.

Diseño/metodología - El marco teórico propuesto se aplicó a una muestra de 636 usuarios de teléfonos móviles. Asimismo, se realizó un análisis multigrupo para comparar si existen diferencias entre los consumidores que realizan research shopping y los compradores unicanal, así como entre los webroomers frente a los showroomers.

Resultados - Los resultados muestran que la conducta research shopping modera la intensidad de la relación entre las emociones y el valor percibido, y entre las emociones y la satisfacción. El análisis del efecto moderador de cada tipología concreta de research shopping evidencia que, en el caso del webrooming, las emociones negativas tienen un efecto negativo sobre el valor percibido y sobre la satisfacción más intenso que en el caso del showrooming.

Originalidad/valor - Este estudio contribuye al estado actual de la investigación sobre la estrategia omnicanal mediante el análisis - a través de un enfoque cognitivo-afectivo- de las consecuencias que el research shopping y cada una de sus dos tipologías básicas (webrooming y showrooming) tienen para los minoristas.

Palabras clave - Research shopping, Webrooming, Showrooming, Emociones, Valor percibido, Satisfacción Tipo de artículo - Trabajo de investigación

\section{Introduction}

Retailing is immersed in the most significant revolution of recent decades, and omnichannel retailing $(\mathrm{OCR})$ is one of the major trends that are transforming the retail sector (World Retail Congress, 2016). OCR is the coordinated management of physical and virtual channels that allow customers to buy at any time and place and obtain a holistic experience between channels (Verhoef et al., 2015; Mosquera et al., 2018).

Studies on current consumption habits have indicated that customers make intensive use of the different touchpoints that are made available by companies and the different electronic devices they have to access a large amount of information about brands, products, opinions and experiences of other users and experts. Currently, customers are research shoppers that use one channel more intensively (whether offline or online) in the information search stage, choosing another alternative channel to acquire the product (Verhoef et al., 2007). Therefore, it is possible to observe two predominant behaviors of research shopping, i.e. webrooming (search online, buy in a physical store) and showrooming (searching for information offline and then buying a product online).

Our literature review suggests that research shoppers constitute a valuable segment for retailers. In this sense, one of the possible issues that should be interesting to study is the influence that variables of cognitive-affective nature have on retailers' commercial strategies.

Specifically, our study focused on determining the possible moderating effect of research shopping $v s$ one-stop shopping and webrooming $v s$ showrooming on the intensity of the relationship between emotions, perceived value (PV) and satisfaction, considering determining factors of customer engagement to retailers (Han and Jeong, 2013).

To achieve this objective, we performed a quantitative research in the Spanish market, choosing mobile phones as a reference product. The results will contribute to the current state of OCR research by the analysis - through a cognitive-affective approach - of the consequences that research shopping and each of its two basic types (webrooming and showrooming) have on retailers.

This study is structured into five sections. In Section 2, we describe the theoretical framework of the research and present the hypotheses. In Section 3, we explain the empirical study conducted for the contrast of the hypotheses previously put forward. Section 4 presents the main 
results. In Section 5, we present the conclusions and implications for management. Finally, in Section 6, we address the main limitations of our study and proposes future lines of research.

\section{Theoretical framework and hypothesis}

\subsection{Moderating effect of research shopping on the relationship between emotions, perceived value and satisfaction}

From the academic and professional points of view, there has been a special interest to know what benefits customers can bring to the companies through the experiences they have during the shopping journey. According to Meyer and Schwager (2007), emotions can be considered an antecedent of the PV (economic and relational) by customers and their satisfaction regarding offers from retailers.

The literature on OCR has focused on determining how customers that develop any omnichannel behavior are more profitable than those who only engage with retailers in one channel (one-stop shoppers). However, these customers are defined by being strict, given that they demand a unique experience through the different touchpoints used to interact with retailers. In this sense, it is necessary to take into account variables of a cognitive-affective nature as a starting point to ensure that this target is loyal and increases its value for retailers.

The success of companies lies in being able to generate positive emotions to their customers so that they can perceive the brand as theirs and, thus, develop greater satisfaction and engagement (Han and Jeong, 2013). On the other hand, if companies generate negative emotions in the customers, the PVs of their offers will be reduced, customer satisfaction will decrease and their propensity to complain and share the experience through word-of-mouth (WOM) will also increase (López-López et al., 2014). In addition, customers might abandon the relationship (Varela-Neira et al., 2014).

In general terms, research shopping might enhance the emotions (both positive and negative) experienced in the shopping journey, thereby influencing the PV and satisfaction. This fact can be explained by resorting to theories about information processing, giving that research shopping implies changes in the way in which customers search, evaluate and compare information.

One of the most relevant models used to study information processing is the elaboration likelihood model (ELM) proposed by Petty and Cacioppo (1986). This model considers that information processing is a continuum, whose extremes are formed by two intensity levels, high and low. This fact will lead to two possible ways by which individuals can process information, i.e. a central route and a peripheral route. Individuals who follow the central route are more motivated and involved in searching for information (Petty and Cacioppo, 1986; Drichoutis et al., 2007). They will examine more critically, deeply and rationally all the information related to the products, increasing the possibility of experiencing emotions during the search process and reinforcing the PV of the offers of companies. On the other hand, individuals who follow the peripheral route will pay less attention to the information or messages received, performing a more superficial processing with fewer opportunities to experience emotions.

The combination of offline and online touchpoints, on the part of research shoppers, facilitates the adoption of the central route to search, obtain, compare and evaluate specific information about products, brands and/or retailers before purchasing. This combination of touchpoints demonstrates a more rational and reflective behavior in which more information is handled and more time and efforts are invested, thus increasing the opportunities to experience emotions and, therefore, improving the PV of the offers of companies. However, according to the study conducted by Rodríguez-Torrico et al. (2017), it should be considered whether the intensive use of mobile phones can influence the development of a more impulsive buying behavior. 
SJME

23,1

The review of the literature performed indicated that customers who seek information online through their smartphones within the physical stores before acquiring the products in such retailer have a more consolidated opinion (Flavián et al., 2016), improving the PV of the offers of the companies and their level of satisfaction. According to Mosquera et al. (2018), the applications included in mobile devices, such as those that allow scanning the QR codes of products, make price comparisons or establish product rankings or the applications of different social networks, in which customers value the products and/or give opinions about their shopping experiences, expand the possibilities of analyzing the PV and facilitate decision-making. In general terms, it can be argued that research shopping is associated with a greater probability of using the central route of information processing, thus increasing the opportunities to experience emotions and, therefore, improving the PV of the offers of companies.

This greater implication inherent in research shopping allows customers to receive a more complete and profound experience of their interactions with retailers. The main attraction of online channels (in addition to aspects such as price or convenience) is the fact that customers can have interactive conversations with the companies. The latter actively listen to the customers and involve them in their management, turning them into "prosumers". For its part, physical stores remain an important point of reference in shopping journey, where the customers can inspect the products not only physically but also in different scenarios provided by the technological implementation of virtual or augmented reality within salesrooms. Another example is the case of clothing stores, in which virtual fitting rooms facilitate customers to see different colors and sizes of the same garments without having to try them on and interact with sellers (Mosquera et al., 2018).

Customers who interact with both types of channels are more likely to have increased involvement with the companies. This way, their positive and negative emotions can be reinforced and intensified. This fact can influence the PV, because it promotes favorable or unfavorable attitudes in the shopping experience. These attitudes can be a filter, i.e. a variable that enhances the perception of value if the attitudes are positive or reduces the perception of values if the attitudes are negative. In this line, Petty et al. (2009) point out that customers' emotions can influence their attitudes, given that the affective component of attitudes is determined by the emotions that the individuals have during the consumption experience (Cohen et al., 2008).

On the other hand, Bagozzi et al. (2016) considered that customers anticipate the positive and negative emotional consequences of the choices they make throughout the different stages of the purchase process. Thus, unlike the previous case, the affective part of attitudes will be determined by the anticipated emotions that the customers experience depending on how they think their customer experience will be with the different distributors they have chosen to search for information about the products they want to buy, and the retailer that has finally been chosen to make the purchase. In summary, the following hypotheses can be put forward:

H1a. The positive relationship between positive emotions and PV is more intense in the case of research shopping than in the case of one-stop shopping.

H1b. The negative relationship between negative emotions and PV is more intense in the case of research shopping than in the case of one-stop shopping.

The development of emotional marketing will affect in the same way as satisfaction (Kwon et al., 2016). However, according to the study conducted by López-López et al. (2014), it should be noted that the level of intensity in the relationship between positive or negative emotions and satisfaction can present certain differences. Retailers should provide pleasurable experiences in both offline and online environments to generate positive emotions (avoiding 
negative emotions) to increase not only the PV but also satisfaction (De Hooge, 2014). Communication centered on favorable messages is also necessary. These messages should provide adequate information to mitigate doubts before, during and after the purchase and avoid cognitive dissonance to favor satisfaction (Bagozzi et al., 2016).

Customers who experience more intense emotions (positive and negative) also have higher (reduced) levels of satisfaction and show greater need to share their emotional experiences with other customers. This may be the case of research shoppers who, by adopting a central route of information processing, have more opportunities to experience emotions with the corresponding greater impact on satisfaction.

In addition, research shoppers who experience positive emotions with retailers will tend to share them with the aim of reliving those pleasurable experiences and ratify the success of their choice. Memories and altruistic work increase customers' positive emotions and satisfaction (Pennebaker and Chung, 2007). In case of experiencing negative emotions, customers may want the retailers to know their discontent so that they can take measures to repair their behavior (Yi and Baumgartner, 2004). Customers can also communicate their negative experience through WOM and e-WOM communication. Reliving bad experiences and finding individuals who support these negative feelings will generate even more discontent in the customers (Byrd-Craven et al., 2007), thus negatively influencing their satisfaction. All these reflections lead us to make the following hypotheses:

H2a. The positive relationship between positive emotions and satisfaction is more intense in the case of research shopping than in the case of one-stop shopping.

$H 2 b$. The negative relationship between negative emotions and satisfaction is more intense in the case of research shopping than in the case of one-stop shopping.

The PV is an antecedent of satisfaction. Customers who have concrete purchasing experiences and perceive the different dimensions that integrate the PV throughout the shopping journey, for which they had certain expectations, will check whether they have been confirmed or not. Such an evaluation gives rise to a certain level of satisfaction. Therefore, the higher the PV, the greater the degree of satisfaction will be (Kesari and Atulkar, 2016).

The study of the concept of PV contemplates its dimensionality, being able to identify two approaches. The one-dimensional approach defines PV as a cognitive trade-off between the quality that customers perceive and the monetary sacrifice they make (SánchezFernández and Iniesta-Bonillo, 2007). This perspective considers that customers are rational beings who only buy products when they can maximize their utility. However, customers also seek to have unique and differentiating experiences during their relationship with retailers (Han and Jeong, 2013) and interact and share their experiences with employees and other customers through offline and online channels (Penz and Hogg, 2011). This is how the multidimensional approach takes into account the utilitarian or functional dimension and the hedonic dimension that includes emotional and social aspects.

In comparison to one-stop shoppers (offline or online), research shoppers, due to the adoption of a central route of information processing, may have a more complete perception of the companies and their offers that include functional-economic and social-emotional dimensions. This way, customers will be able to take advantage of the utilities and advantages provided by physical and virtual channels.

Traditionally, online channels have been linked to the promotion of utilitarian values, such as economic savings, time and effort, comfort, convenience or the available assortment. The hedonic value should also be strengthened given that, in many cases, the first contact between retailers and customers occurs through the Internet. 
SJME

23,1

50

A website designed with a structure that favors usability and Web browsing accessible from any device (responsive design), with a combination of colors, images and graphics that draw attention (Flavián et al., 2009; Rose et al., 2012), will enhance the hedonic value of online channels. In the same way, according to Flavián et al. (2009), the quality of the information provided by retailers on their websites about the product portfolio they sell (detailing prices and main characteristics, providing images from various angles or in 3D format, showing complementary products, etc.) and about other aspects and services (contact forms, delivery times, purchase history, personalized advices and recommendations, opinions of experts and influencers, etc.) entails that virtual channels are less impersonal and that the customers can interact with the retailers considering not only attributes of utilitarian value but also activities associated with other dimensions of functional and hedonic character that integrates the PVs (Yoo et al., 2015).

For its part, it is advisable to enhance hedonic values in offline channels (without forgetting the utilitarian aspect), thus allowing customers to examine the products physically and use their senses, interact with other individuals and receive personalized advice. Through their architecture, internal layout, lighting, colors, background music and smell, physical stores can also facilitate the development of customers' positive perceptions. Likewise, the inclusion of instore information and communication technologies (ICTs), such as augmented reality, virtual fitting rooms or iBeacon technology, can improve the shopping experience (Mosquera et al., 2018).

This way, it seems that research shopping influences the customers to develop a more complete perception of the retailers as a result of the adoption of a central route of information processing. In addition, it can reduce the risks associated with the use of a single channel, especially if it is the internet, which positively makes customers feel more satisfied. The proposed hypothesis is the following:

H3. The positive relationship between PV and satisfaction is more intense in the case of research shopping than in the case of one-stop shopping.

Figure 1 shows the hypotheses relating to the moderating effect of research shopping.

\subsection{Webrooming and showrooming as moderators of the relationship between emotions, perceived value and satisfaction}

According to the characteristics that define webrooming with respect to showrooming, there could be differences in the way in which the customers process the information and, therefore, generate differences in the intensity of the relationship between emotions, PV and satisfaction.

Webrooming is more associated to a central route than showrooming. Webroomers first consult the internet to obtain information about a product, making comparisons with other

Figure 1.

Research proposal

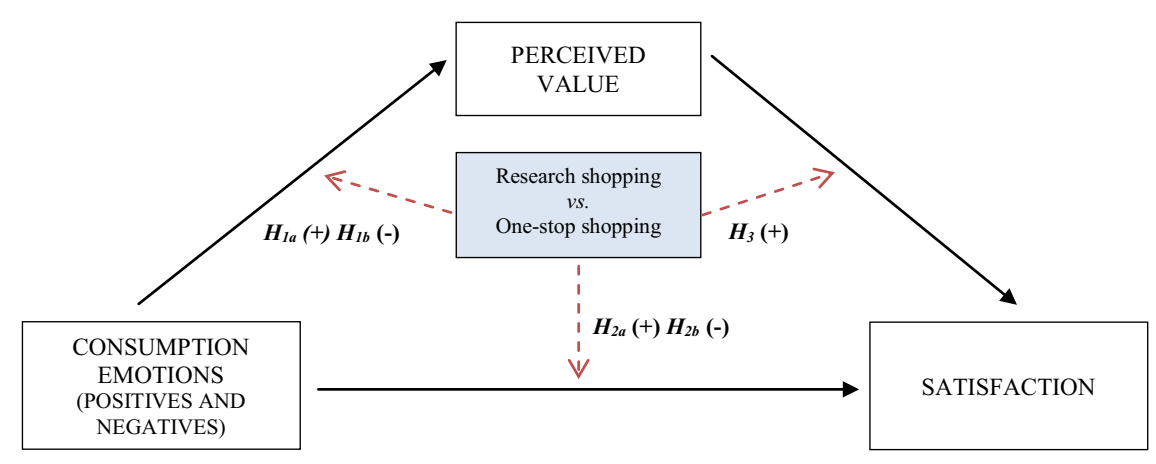


similar products and analyzing other customer ratings. Subsequently, they go to physical stores, where they finally make purchases with an opinion of what they want to acquire. Even, within the physical stores, webroomers can complete or improve the information previously obtained by consulting their smartphones (Flavián et al., 2016; Mosquera et al., 2018). In the salesrooms, customers analyze the products either physically or aided by technological applications and receive advice from sales personnel, while already having considerable prior information and knowing what they want.

On the other hand, even though showroomers also show involvement in the purchase by combining physical and virtual channels, it is possible that they do not have sufficient information about the characteristics of the products at the time they go to the physical stores, exhibiting a less consolidated attitude than webroomers regarding the type of products to be acquired (Rapp et al., 2015; Yurova et al., 2016). Given the confidence that showrooming customers develop through virtual channels, and the intensive use they make of their smartphones (GfK, 2015), it can be assumed that their purchases will be less planned in comparison to those of webroomers (Rodríguez-Torrico et al., 2017). In this sense, retailers will try to encourage impulse purchases due to the characteristics of these devices and the existence of multiple mobile marketing actions (San-Martín and López-Catalán, 2013).

In summary, webrooming is a more planned behavior than showrooming, given that webroomers use the mix of touchpoints, offline and online, which they consider optimal to look for information that allows them to anticipate what their shopping experience will be like (positive or negative) depending on the retailers chosen (Bagozzi et al., 2016). This fact means that their attitude in all the stages that make up this process is choosing the retailer that represents the best option. This greater involvement in the shopping journey is more likely to enhance the "activation" dimension of emotions, making webroomers perceive a greater value of the companies, which influences satisfaction during the shopping journey. Therefore, we can put forward the following hypotheses:

H4a. The positive relationship between positive emotions and PV is more intense in the case of webrooming than in the case of showrooming.

$H 4 b$. The negative relationship between negative emotions and $\mathrm{PV}$ is more intense in the case of webrooming than in the case of showrooming.

H5a. The positive relationship between positive emotions and satisfaction is more intense in the case of webrooming than in the case of showrooming.

$H 5 b$. The negative relationship between negative emotions and satisfaction is more intense in the case of webrooming than in the case of showrooming.

H6. The positive relationship between PV and satisfaction is more intense in the case of webrooming than in the case of showrooming.

Figure 2 shows the proposed theoretical model.

\section{Research method}

3.1 Research scope and sample design

To test the proposed hypotheses, we performed an empirical research choosing smartphones as a reference product, which has a use rate of 80 per cent in Spain (Ditrendia, 2018). Smartphones can be considered an experience product (Ekelund et al., 1995). Customers cannot assess a priori whether the choice of one mobile phone over another (for example, Android $v s$ iOS mobile operating systems) will provide them with greater utility, 
SJME

23,1

\section{2}

Figure 2.

Research proposal positive experiences or satisfaction. This way, to avoid the risks associated with purchases, customers seek information by developing any of the research shopping, webrooming or showrooming behaviors (ONTSI, 2017).

To achieve the objectives of the present study, we performed a personal survey. Table I shows the research data. The profile of the sample is shown in Appendix 1.

\subsection{Measurement of the model variables}

The measurement of emotions, PV and satisfaction was performed through a series of items obtained in the literature review on the subject. All the items were evaluated using a 11point Likert scale. Appendix 2 shows the scales and items used.

As far as emotions are concerned, they have not been analyzed just at the moment they occurred, but a posteriori. The quick and ephemeral nature of emotions seems to suggest that the first option is more advisable. However, the high cost of this method and its intrusive consideration by individuals means that a posteriori measurement remains the most widespread technique. Studies as those conducted by Jaeger et al. (2013), King et al. (2013) and Piqueras-Fiszman and Jaeger (2014a, 2014b) have demonstrated this fact, evidencing that emotions experienced during the use or consumption of products function as a selection system. Customers store in their memories and in a prolonged manner the facts that have special emotional meanings, which can be positive (De Hooge, 2014) or negative (Frijda, 1988). This way, these facts are more easily remembered.

Regarding PV, we focused on the studies conducted by Fandos et al. (2006), Moliner et al. (2005), Sánchez et al. (2006) and Sweeney and Soutar (2001). Considering these works, we measured the PV from two of its basic dimensions, i.e. the functional value (FV) and the social value (SV). The FV dimension is composed of three items, namely:

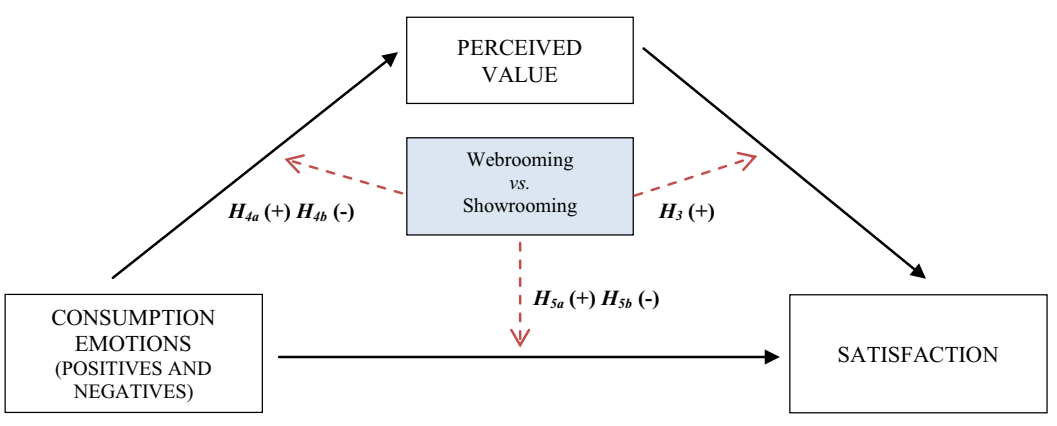


- FV of the company;

- FV of sales personnel; and

- $\mathrm{FV}$ of the price.

After confirming the reliability and validity of the FV and SV, we combined the two scales into a second-order factor, which was called PV.

Research shopping was measured through three types of questions (Appendix 2). First, we used a dichotomous question, in which the respondents specified whether they had made the purchase through a single channel (regardless of whether it was offline or online) or, on the contrary, had used both the physical and the virtual channels. Subsequently, to determine whether their behaviors had indeed been research shopping or one-stop shopping, we included a question that referred to offline and/or online information sources used during the shopping journey and the place (physical or virtual stores) chosen to acquire the mobile phones. Finally, research shopping was measured through a ten-point scale[1], in which 1 referred to the use of a single channel (whether physical or virtual) and 10 referred to the combined use of offline and online channels to choose and buy the mobile phones.

Finally, the measurement of webrooming and showrooming was performed by means of a dichotomous question. The respondents specified which channel they had used most intensively to look for pre-purchase information and which channel they had chosen to purchase their mobile phones (Appendix 2).

\subsection{Reliability and validity of the scales}

Reliability was assessed using Cronbach's alpha reliability coefficient and the compound reliability coefficient (in all cases they exceeded the value 0.7 ). We also assessed the validity of the content (the scales had been validated in previous studies), convergent validity (the standardized lambda of the relationship between the observed variable and the latent variable were significant and greater than 0.5) and discriminant validity (the confidence intervals of all the correlations between the concepts analyzed did not contain the unit value, and its squared value did not exceed the average variance extracted - AVE - in the measurement scales considered). Finally, the AVE was calculated as an indicator of the convergent validity of each scale, exceeding in all cases the minimum value of 0.5 (Appendix 2).

\section{Results}

\subsection{Moderating effect of research shopping}

We performed a multigroup analysis using the EQS 6.2 software for Windows and the robust maximum likelihood method (ML Robust) to contrast the proposed hypotheses concerning the moderating effect of research shopping (261 respondents) in comparison to one-stop shopping behavior (375 respondents).

The multigroup analysis requires reporting the statistical power of the test to validate the study design and interpret the results as accurately as possible. This issue is especially relevant when working with small sample sizes, in which no significant results are obtained (the possibility of detecting a true effect is reduced) or the probability that a significant result reflects a true effect is reduced (Cohen, 1988). According to Cohen (1988), the recommended statistical power is 80 per cent. In the present study, we obtained a statistical power of 80.3 per cent ( $\mathrm{G} *$ Power 3.1 software), thus validating the results obtained.

The results (Figure 3 and Appendix 3) indicated that both positive and negative emotions influenced the PV. This influence was significantly greater in the case of research shopping than in the case of one-stop shopping, although only for positive emotions. 


\section{Figure 3.}

Measurement model for research shopping versus one-stop shopping

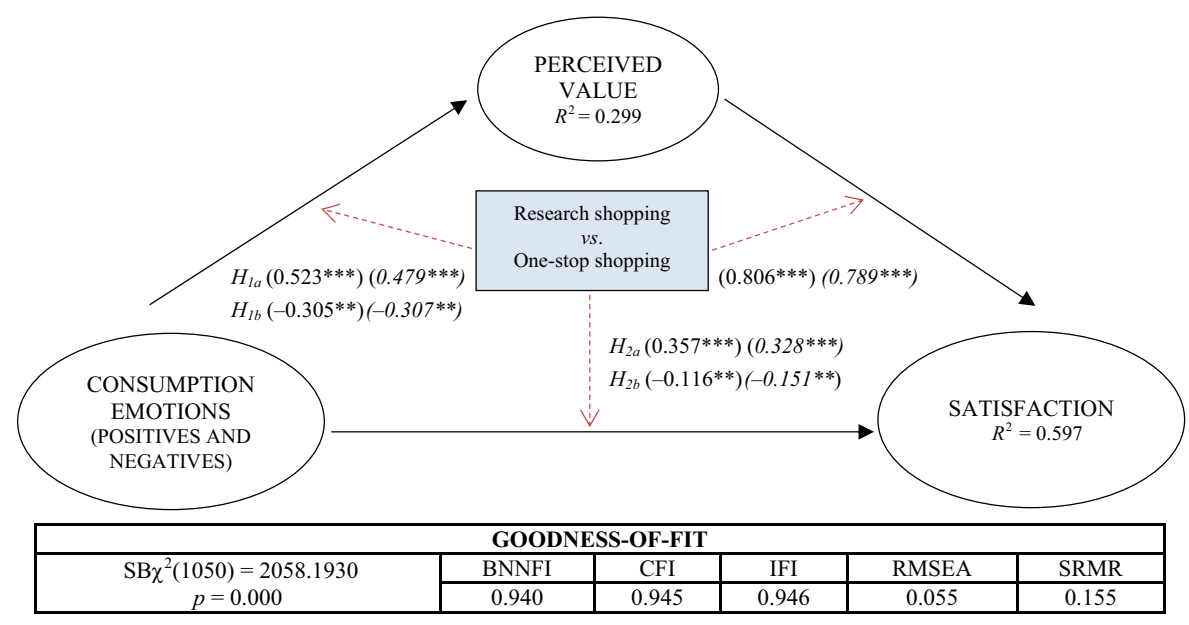

Notes: ${ }^{*} p<0.10 ;{ }^{* *} p<0.05 ;{ }^{* * *} p<0.001$

Therefore, we accepted $H 1 a$, and $H 1 b$ was rejected. Positive and negative emotions also influenced satisfaction, and this influence was significantly greater in the case of research shopping regarding positive emotions. Again, we did not observe significant differences for negative emotions. Therefore, we accepted $H 2 a$, and $H 2 b$ was rejected. On the other hand, $\mathrm{PV}$ influenced satisfaction, and this influence was greater in the case of research shopping than in the case of one-stop shopping, giving support to $H 3$.

To assess the mediating effect of the PV, we compared two models using structural equation modeling (SEM) and the $\chi^{2}$ difference test. According to Cheung and Lau (2008) and Iacobucci et al. (2007), SEM is the most appropriate technique for calculating the effects of mediation when the models are composed of dependent, mediating and latent independent variables with several indicators. For its part, $\chi^{2}$ difference test is used to determine the improvement of a model adjustment with respect to an alternative model. A model adjustment in comparison to an alternative model is considered acceptable when the probability of the $\chi^{2}$ difference test value with respect to the degrees of freedom required is significant $(\phi<0.05)$.

Appendix 4 illustrates the restricted model, showing the total mediation of PV between emotions (independent variable) and satisfaction (dependent variable). The second model proposed (Figure 3) described the partial mediation of PV, taking into account the direct and indirect effects of the independent variable (emotions) and the dependent variable (satisfaction). Appendix 4 shows the results of the two models, and the $\chi^{2}$ difference test, which was significant, indicated that the model of partial mediation obtained better results $\left[\Delta \chi^{2}(68)=607.067, p=0.000\right]$. Therefore, it can be concluded that the PV had a partial mediating effect between emotions (positive and negative) and satisfaction, both for research shoppers and one-stop shoppers.

\subsection{Moderating effect of webrooming and showrooming}

To contrast the hypotheses about the moderating effect of webrooming $v s$ showrooming, we performed a multigroup analysis distinguishing two groups: webroomers (217 respondents) and showroomers (44 respondents). The statistical power obtained was 45.3 per cent 
(G*Power 3.1 software). Without being an optimal value, it exceeded the minimum desirable limits (Cohen, 1988; Bono and Arnau, 1995), indicating that an effect such as the proposed one will be detected 45.3 per cent of the times.

The results (Figure 4 and Appendix 3) indicated that emotions influenced PV and satisfaction, and that this influence was significantly greater in the case of webrooming than in the case of showrooming, although only for negative emotions (no significant differences were observed for positive emotions). Therefore, $H 4 b$ and $H 5 b$ were confirmed, whereas there was no evidence to confirm $H 4 a$ and $H 5 a$. The results also indicated the possible influence of PV on satisfaction. However, no significant differences were observed between the two groups of customers assessed, so there was no evidence to accept $H 6$.

To determine whether the PV had total mediation effect (Appendix 5) or partial mediation effect (Figure 4), we compared the two models using SEM. The results illustrated in Appendix 5 and the $\chi^{2}$ difference test indicated that the partial mediation model obtained better results $\left[\Delta \chi^{2}(68)=381.244, p=0.000\right]$. Therefore, it can be concluded that PV had a partial mediating effect between emotions (positive and negative) and satisfaction, both for webroomers and showroomers.

\section{Conclusions}

The goal of the present study was to determine whether research shopping and its basic types - i.e. webrooming and showrooming - had a moderating effect on the intensity of the relationship between emotions, $\mathrm{PV}$ and satisfaction.

Although several studies have addressed the impact of research shopping on the volume of purchases made by the customers, or other quantitative measures of behavior, the literature focused on its influence on the variables of cognitive-affective type is much scarcer, even though their analysis is necessary in the current retail environment to achieve customer engagement.

There is no consensus on the variables that compose the cognitive-affective model, given that emotions and PV are a priority research area in the OCR literature, and that together with satisfaction, they are considered a precedent of the engagement that contributes to

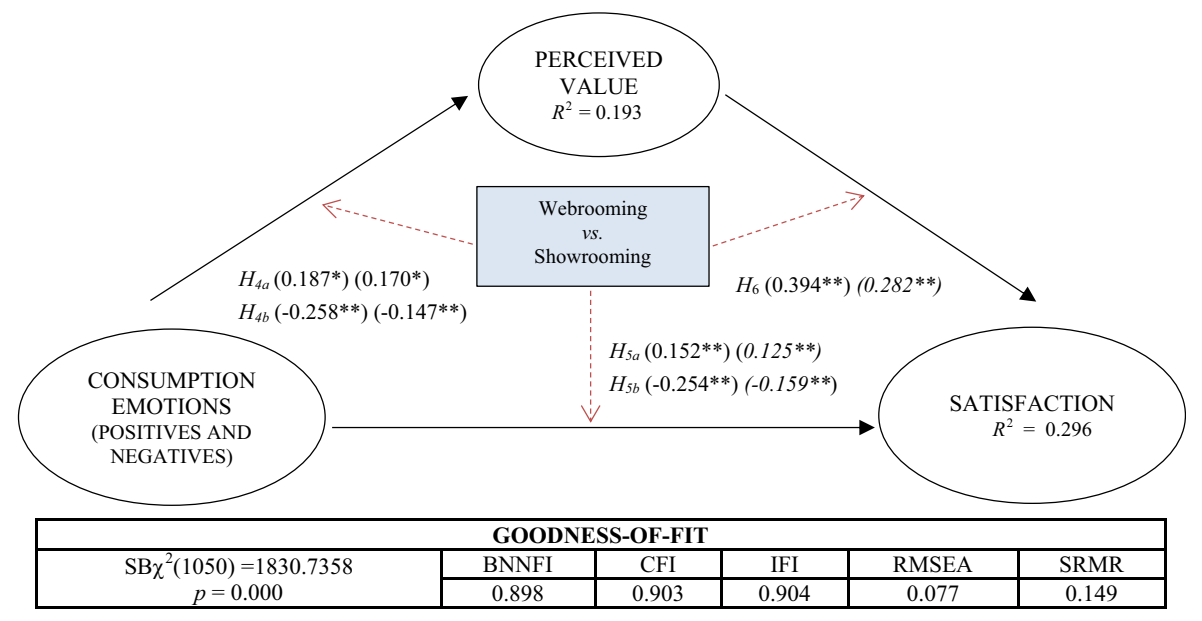

Notes: ${ }^{*} p<0.10 ;{ }^{* *} p<0.05 ;{ }^{* * *} p<0.001$

Figure 4. Measurement model for webrooming versus showrooming 
increase the value (economic and relational) of retail companies (Kwon et al., 2016; Son and $\mathrm{Qu}, 2017)$. However, we decided to use a cognitive-affective model that relates these three variables.

The present study allowed us to reach different conclusions. In the first place, it was possible to observe how positive emotions had a significantly greater positive direct impact in the case of research shopping than in the case of one-stop shopping, both on the PV (FV and SV) and satisfaction. In addition, the relationship between PV and satisfaction was more intense and positive in the case of research shoppers. Although negative emotions also negatively influenced PV and satisfaction, no differences were observed between the two groups of customers assessed. In any case, the influence of negative emotions on PV and satisfaction was lower than the influence of positive emotions.

Taking into account these results, it seems that enhancing the hedonic (positive emotional experiences) and functional dimensions (utilitarian experiences) of the offline and online channels turned out to be a condition for satisfying research shoppers. The development of these two dimensions will help these customers - with greater association to the central information processing route - receive a more complete shopping experience in their interactions with retailers.

The results also indicated that the PV had a partial mediating effect between emotions (positive and negative) and satisfaction, both for research shoppers and onestop shoppers. Current customers consider the functional aspects of PV as a commodity, and not providing these attributes can result in a loss of sales volume for retailers (Nielsen, 2017). Satisfaction of research shoppers is obtained by not only increasing the PV (functional and social) but also experiences that surpass their expectations in all the offline and online touchpoints.

Second, with respect to the assessment of webrooming $v s$ showrooming, the PV had a partial mediating effect between emotions (positive and negative) and satisfaction for the two groups of customers. The results indicated that in the case of webrooming, negative emotions had a more intense direct negative effect on PV (FV and SV) and satisfaction than in the case of showrooming. In addition, the results also indicated the positive influence of PV on satisfaction; however, no significant differences were observed between the two groups of customers assessed. On the other hand, although positive emotions also influenced the PV and satisfaction in a positive manner, there were no differences between webrooming and showrooming. In any case, the influence of positive emotions on PV and satisfaction was lower than that of negative emotions.

In the specific case of buying smartphones, webroomers had a free-riding behavior. These customers, characterized by having a less impulsive buying behavior and being more associated with the central information processing route than showroomers, considered the internet as a suitable source of information that could be used to reduce the risks associated with the purchase of this type of product. They also considered physical stores - where they finally bought the products - as the channel that served to complete or improve the information. If the internet did not provide the right information to form a specific opinion, the products were not available in the salesrooms or the sales staff did not resolve doubts, the expectations that they had were not met, thus having a negative impact on their satisfaction. In this sense, the status of research shoppers had a positive influence on the use of ICTs, which allowed them to discuss their shopping experiences with other individuals, especially if they were negative (Frijda, 1988; López-López et al., 2014). 


\section{Managerial implications}

Although the terms "omnichannel shopper" or "research shopper" are often used in the academic literature and in the professional language, associated with a type of buyers who use multiple offline and online touchpoints to interact with the companies and who are homogeneous in terms of their characteristics, the present study was able to confirm that within these generic labels, there are currently at least two differentiated behaviors toward which marketing strategies should be directed, specifically those related to the generation of experiences and emotions.

In the case of webroomers, retailers should take care of their presence on the internet. They should ensure that their websites are usable, exhibiting an intuitive and visually attractive content structure, being indexable, sociable and with a responsive design aimed at providing complete information about products. Inside the physical stores, it would be interesting to make efforts aimed at increasing the length of stay of webroomers, given that, in broad terms, they arrive at the salesrooms with a very specific idea of what they want to buy.

Some strategies that can be applied are the provision of personalized attention to enhance cross-selling and up-selling, good after-sales services and the incorporation of in-store ICTs so that the sellers can provide comparisons or additional online information. This way, customers will receive a more complete and differentiating shopping experience, being able to test the products in different scenarios (Mosquera et al., 2018).

Showroomers could be an opportunity for retailers. Their more impulsive buying behavior leads, with greater probability, to finally buy higher-priced products, at least those considered hedonic (Kushwaha and Shankar, 2013), although they then look for the distributors that have lower prices for that price-quality schema (Gensler et al., 2017). Therefore, the recommendations in this case would be essential, because the retailers would encourage their sales forces to take the initiative in the physical stores and show these buyers the products for which the companies are well positioned with respect to prices. This way, if desired, buyers would acquire these products in any of the virtual touchpoints of the retailers. In addition, retailers should highlight the possible advantages that the customers might have by acquiring the products in the physical store instead of acquiring them online.

It is worth reflecting whether, in spite of the current existence of these two types of customers (webroomers and showroomers), their differences will be diluted in the future, and a single category of customer will be considered. In any case, if the behaviors tend to converge or, on the contrary, new and differentiated behaviors appear, the future of the retailing sector will be characterized by omnichannelity (von Briel, 2018).

The strategy should be linked to a deep orientation toward customers and managing the offline and online channels together to provide a holistic experience. Retailers should build an "omni brand", because current customers - defined as "channel agnostic", because they have less and less propensity to use a single channel during their shopping journey - do not want to interact with the channels but with the brands and also want to receive global solutions (Mosquera et al., 2018).

\section{Limitations and future lines of research}

Among the most important limitations of the present study, it is worth mentioning that only the cognitive-affective consequences have been analyzed using three variables (emotions, $\mathrm{PV}$ and satisfaction), given that there are other dimensions that may be the subject of future studies. Also, due to the fact that the study of the moderating effect of the two types of research shopping (webrooming and showrooming) on the relationship between emotions, 
PV and satisfaction obtained a low index of statistical power (45.3 per cent), the results should be interpreted with some caution.

Future research could be aimed at conducting a joint study to assess the drivers that influence the development of research shopping and, as a consequence, the effects of such behavior on companies. Likewise, it would be interesting to study other retail sectors to evaluate whether the variables studied produce the same results. This would be the case of textile products, fashion, footwear, sports equipment, technical consumer goods, beauty and other goods/services in the luxury market, where there is a high degree of OCR implementation (GfK, 2017). It would also be relevant to assess the fast-moving consumer goods sector; although currently it has a low e-commerce index, it is expected that such rates will increase due to the challenge that traditional retailers have faced with the arrival of companies such as Amazon, traditionally called "pure players" (Nielsen, 2017).

\section{Note}

1. In this case, we decided to use a 10-point scale because, after analyzing the results of the pre-test performed before preparing the last version of the questionnaire, it was found that including the value 0 gave rise to doubts in the answers of the participants. The respondents understood that the value 0 indicated not having used any channel.

\section{References}

Bagozzi, R.P., Belanche, D., Casaló, L.V. and Flavián, C. (2016), “The role of anticipated emotions in purchase intentions", Psychology and Marketing, Vol. 33 No. 8, pp. 629-645.

Bloemer, J.M.M. and Odekerken-Schröder, G. (2002), "Store satisfaction and store loyalty explained by customer and store related factors", Journal of Consumer Satisfaction, Dissatisfaction and Complaining Behavior, Vol. 15, pp. 68-80.

Bono, R. and Arnau, J. (1995), "Consideraciones generales en torno a los estudios de potencia”, Anales de Psicología, Vol. 11, pp. 193-202.

Byrd-Craven, J., Geary, D.C., Rose, A.J. and Ponzi, D. (2007), "Co-ruminating increases stress hormone levels in women", Hormones and Behavior, Vol. 53 No. 3, pp. 192-489.

Cheung, G.W. and Lau, R.S. (2008), "Testing mediation and suppression effects of latent variables: bootstrapping with structural equation models", Organizational Research Methods, Vol. 11 No. 2, pp. 296-325.

Cohen, J. (1988), Statistical Power Analysis for the Behavioral Sciences, Lawrence Erlbaum Associates, NJ.

Cohen, J.B., Pham, T.P., Andrade., and E.B. (2008), "The nature and role of affect in consumer behavior", in Haugtvedt, C., Kardes, F. and Herr, P. (Eds), Handbook of Consumer Psychology, Mahwah, NJ, pp. 297-348.

De Hooge, I.E. (2014), "Predicting consumer behavior with two emotion appraisal dimensions: emotion valence and agency in gift giving", International Journal of Research in Marketing, Vol. 31 No. 4, pp. 380-394.

Ditrendia (2018), "Mobile en españa y enm el undo", available at: http://mktefa.ditrendia.es/blog (accessed 14 October 2018).

Drichoutis, A.C., Lazaridis, P. and Nayga, R.M. Jr (2007), "An assessment of product class involvement in food purchasing behavior”, European Journal of Marketing, Vol. 41 Nos 7/8, pp. 888-914.

Ekelund, R.B., Mixon, F.G. and Ressler, R.W. (1995), "Advertising and information: an empirical study of search, experience and credence goods”, Journal of Economic Studies, Vol. 22 No. 2, pp. 33-43. 
Fandos, J.C., Sánchez, J., Moliner, M.A. and Llorens, J. (2006), "Customer perceived value in banking services”, International Journal of Bank Marketing, Vol. 24 No. 5, pp. 266-283.

Flavián, C., Gurrea, R. and Orús, C. (2009), "Web design: a key factor for the website success", Journal of Systems and Information Technology, Vol. 11 No. 2, pp. 168-184.

Flavián, C., Gurrea, R. and Orús, C. (2009), "The effect of product presentation mode on the perceived content and continent quality of web sites", Online Information Review, Vol. 33 No. 6, pp. 1103-1128.

Flavián, C., Gurrea, R. and Orús, C. (2016), "Choice confidence in the webrooming purchase process: the impact of online positive reviews and the motivation to touch", Journal of Consumer Behaviour, Vol. 15 No. 5, pp. 459-476.

Frijda, N.H. (1988), “The laws of emotion”, The American Psychologist, Vol. 43 No. 5, pp. 349-358.

Gensler, S., Neslin, S.A. and Verhoef, P.C. (2017), "The showrooming phenomenon: it's more than just about price", Journal of Interactive Marketing, Vol. 38, pp. 29-43.

GfK (2015), “Cómo utilizan los consumidores el teléfono móvil en las tiendas 2014”, available at: www.gfk. com/es/insights/press-release/tomar-fotos-contactar-con-amigos-y-comparar-precios-los-usos-masfrecuentes-del-movil-en-las-tiendas-en-espana/ (accessed 15 May 2017).

GfK (2017), "GfK clima de consumo Para europa, tercer trimestre de 2017", available at: www.gfk.com/ es/insights/press-release/gfk-clima-de-consumo-para-europatercer-trimestre-de-2017/ (accessed 15 May 2018).

Han, H. and Jeong, C. (2013), 'Multi-dimensions of patrons' emotional experiences in upscale restaurants and their role in loyalty formation: emotion scale improvement", International Journal of Hospital Management, Vol. 32, pp. 59-70.

Iacobucci, D., Saldanha, N.Y. and Deng, X. (2007), "A meditation on mediation: evidence that structural equations models perform better than regressions", Journal of Consumer Psychology, Vol. 17, pp. 140-154.

Jaeger, S.R., Cardello, A.V. and Schutz, H.G. (2013), "Emotion questionnaires: a consumer-centric perspective", Food Quality and Preference, Vol. 30 No. 2, pp. 229-241.

Kesari, B. and Atulkar, S. (2016), "Satisfaction of mall shoppers: a study on perceived utilitarian and hedonic shopping values", Journal of Retailing and Consumer Services, Vol. 18, pp. 22-31.

King, S.C., Meiselman, H.L. and Carr, T. (2013), "Measuring emotions associated with foods: important elements of questionnaire and test design", Food Quality and Preference, Vol. 28 No. 1, pp. 8-16.

Kushwaha, T. and Shankar, V. (2013), "Are multichannel customers really more valuable? the moderating role of product category characteristics", Journal of Marketing, Vol. 77 No. 4, pp. 67-85.

Kwon, H., Ha, S. and Im, H. (2016), "The impact of perceived similarity to other customers on shopping mall satisfaction", Journal of Retailing and Consumer Services, Vol. 28, pp. 304-309.

Laros, F.J.M. and Steenkamp, J.B.E. (2005), "Emotions in consumer behavior: a hierarchical approach", Journal of Business Research, Vol. 58 No. 10, pp. 1437-1445.

López-López, I., S., Ruiz-de-Maya, S. and Warlop, L. (2014), "When sharing consumption emotions with strangers is more satisfying than sharing them with friends", Journal of Service Research, Vol. 17 No. 4, pp. 475-488.

Meyer, C. and Schwager, A. (2007), "Understanding customer experience", Harvard Business Review, Vol. 85 No. 2, pp. 116-126.

Moliner, M.A., Sánchez, J., Rodríguez, R.M. and Callarisa, L. (2005), "Dimensionalidad del valor percibido global de una compra", Revista Española de Investigación de Marketing ESIC, Vol. 16, pp. 135-158.

Mosquera, A., Olarte-Pascual, C., Juaneda Ayensa, E. and Sierra Murillo, Y. (2018), "The role of technology in an omnichannel physical store: assessing the moderating effect of gender", Spanish Journal of Marketing, Vol. 22 No. 1, pp. 63-82. 
SJME

23,1

Nielsen (2017), "Lo que se viene en e-commerce", available at: www.nielsen.com/content/dam/ nielsenglobal/latam/docs/reports/Reporte\%20E-Commerce $\% 20$ espa $\%$ C3\%B1ol.pdf (accessed 17 May 2017).

Oliver, R. (1999), “Whence consumer loyalty?”, Journal of Marketing, Vol. 63 No. 4, pp. 33-45.

ONTSI (2017), "Estudio sobre comercio electrónico B2C (Edición 2017)", available at: www.Ontsi.Red.Es/ Ontsi/Es/Content/Estudio-Sobre-Comercio-Electr\%C3\%B3nico-B2c-Edici\%C3\%B3n-2017 (accessed 16 May 2018).

Pennebaker, J.W. and Chung, C.K. (2007), "Expressive writing, emotional upheavals, and health", in Friedman, H. and Silver, R. (Eds), Handbook of Health Psychology, New York, NY, pp. 263-284.

Penz, E. and Hogg, M.K. (2011), "The role of mixed emotions in consumer behavior: investigating ambivalence in consumers' experiences of approach-avoidance conflicts in online and offline settings", European Journal of Marketing, Vol. 45 Nos 1/2, pp. 104-132.

Petty, R., Briñol, P. and Priester, J.R. (2009), "Mass media and attitude change: implications of the elaboration likelihood model of persuasion", in Bryant, J. and Oliver, M.B. (Eds), Media Effects: Advances in Theory and Research, New York, NY, pp. 125-164.

Petty, R.E. and Cacioppo, J.T. (1986), Communication and Persuasion: Central and Peripheral Routes to Attitude Change, Springer-Verlag, New York, NY.

Piqueras-Fiszman, B. and Jaeger, S.R. (2014a), "Emotion responses under evoked consumption contexts: a focus on the consumers' frequency of product consumption and the stability of responses", Food Quality and Preference, Vol. 35, pp. 24-31.

Piqueras-Fiszman, B. and Jaeger, S.R. (2014b), "The impact of evoked consumption contexts and appropriateness on emotion responses", Food Quality and Preference, Vol. 32, pp. 277-288.

Rapp, A., Baker, T.L., Bachrach, D.G., Ogilvie, J. and Beitelspacher, L.S. (2015), "Perceived customer showrooming behavior and the effect on retail salesperson self-efficacy and performance", Journal of Retailing, Vol. 91 No. 2, pp. 358-369.

Rodríguez-Torrico, P., San-Jose Cabezudo, R. and San-Martín, S. (2017), "Tell me what they are like and I will tell you where they buy: an analysis of omnichannel consumer behavior", Computers in Human Behavior, Vol. 68, pp. 465-471.

Rose, S., Clark, M., Samouel, P. and Hair, N. (2012), "Online customer experience in e-retailing: an empirical model of antecedent and outcomes", Journal of Retailing, Vol. 88 No. 2, pp. 308-322.

Sánchez, J., Callarisa, L., Rodríguez, R.M. and Moliner, M.A. (2006), "Perceived value of the purchase of a tourism product”, Tourism Management, Vol. 27 No. 3, pp. 394-409.

Sánchez-Fernández, R. and Iniesta-Bonillo, M.A. (2007), "The concept of perceived value: a systematic review of the research", Marketing Theory, Vol. 7 No. 4, pp. 427-451.

San-Martín, S. and López-Catalán, B. (2013), "How can a mobile vendor get satisfied customers?", Industrial Management and Data Systems, Vol. 113 No. 2, pp. 156-170.

Smith, A.K. and Bolton, R.N. (2002), "The effect of customers" emotional responses to service failures on their recovery effort evaluations and satisfaction judgment", Journal of the Academy Marketing Science, Vol. 30 No. 1, pp. 5-23.

Son, J. and Qu, H. (2017), "The mediating role of consumption emotion", International Journal of Hospitality Management, Vol. 66, pp. 66-76.

Sweeney, J.C. and Soutar, G.N. (2001), "Consumer perceived value: the development of multiple item scale", Journal of Retailing, Vol. 77 No. 2, pp. 203-220.

Varela-Neira, C., Vázquez-Casielles, R. and Iglesias, V. (2014), "Intentionality attributions and humiliation: the impact on customer behavior", European Journal of Marketing, Vol. 48 Nos 5/6, pp. 901-923.

Verhoef, C., Neslin, S. and Vroomen, B. (2007), "Multichannel customer management: understanding the research shopper phenomenon", International Journal of Research in Marketing, Vol. 24 No. 2, pp. 129-177. 
Verhoef, P.C., Kannan, P.K. and Inman, J.J. (2015), "From multi-channel retailing to omni-channel retailing: introduction to the special issue on multi-channel retailing", Journal of Retailing, Vol. 91 No. 2, pp. 174-181.

von Briel, F. (2018), "The future of omnichannel retail: a four-stage Delphi study", Technological Forecasting and Social Change, Vol. 132, pp. 217-229.

White, C. and Yu, Y. (2005), "Satisfaction emotions and the consumer behavioral intentions", Journal of Services Marketing, Vol. 19 No. 6, pp. 411-420.

World Retail Congress (2016), "The future of retail: 8 key predictions", available at: www. worldretailcongress.com/news/future-retail-8-key-predictions (accessed 10 November 2017).

Yi, S.H., and Baumgartner, H. (2004), "Coping with negative emotions in purchase-related situations", Journal of Consumer Psychology, Vol. 14 No. 3, pp. 303-317.

Yoo, C.W., Kim, Y.J. and Sanders, G.L. (2015), "The impact of interactivity of electronic word of mouth systems and e-quality on decision support in the context of the e-marketplace", Information and Management, Vol. 52 No. 4, pp. 496-505.

Yurova, Y., Rippé, C.B., Weisfeld-Spolter, S., Sussan, F. and Arndt, A. (2016), "Not all adaptive selling to omni-consumers is influential: the moderating effect of product type", Journal of Retailing and Consumer Services, Vol. 34, pp. 271-277. 
SJME

Appendix 1

23,1

\begin{tabular}{|c|c|c|c|c|c|c|}
\hline \multirow[b]{2}{*}{62} & & Sample & \multicolumn{2}{|c|}{$\begin{array}{c}\text { Research shoppers } \\
261(41.04 \%)\end{array}$} & \multicolumn{2}{|c|}{$\begin{array}{c}\text { One-stop shoppers } \\
375(58.96 \%)\end{array}$} \\
\hline & & $636(100.00 \%)$ & $\begin{array}{l}\text { Webroomers } \\
217(83.14 \%)\end{array}$ & $\begin{array}{c}\text { Showroomers } \\
44(16.86 \%)\end{array}$ & $\begin{array}{c}\text { Offline shoppers } \\
331(88.27 \%)\end{array}$ & $\begin{array}{c}\text { Online shoppers } \\
44(11.73 \%)\end{array}$ \\
\hline & $\begin{array}{l}\text { Gender } \\
\text { Male }\end{array}$ & $303(47.60 \%)$ & $129(49.43 \%)$ & & $174(46.40 \%)$ & \\
\hline & & & $109(50.23 \%)$ & $20(45.45 \%)$ & $152(45.92 \%)$ & $22(50.00 \%)$ \\
\hline & Female & $333(52.40 \%)$ & $132(50.57 \%)$ & $24(5455 \%)$ & $\begin{array}{l}201(53.60 \%) \\
179(54.08 \%)\end{array}$ & $22(50.00 \%)$ \\
\hline & Age & & & $24(54.55 / 0)$ & $179(54.00 \%)$ & $22(00.00 / 0)$ \\
\hline & $15-24$ years & $81(12.70 \%)$ & $\begin{array}{l}50(19.16 \%) \\
46(21.20 \%)\end{array}$ & $4(9.09 \%)$ & $\begin{array}{l}31(8.27 \%) \\
28(8.46 \%)\end{array}$ & $3(6.82 \%)$ \\
\hline & $25-44$ years & $281(44.20 \%)$ & $145(55.56 \%)$ & & $136(36.27 \%)$ & \\
\hline & & & $110(50.69 \%)$ & $35(79.55 \%)$ & $100(30.31 \%)$ & $36(81.82 \%)$ \\
\hline & 45-64 years & $169(26.60 \%)$ & $50(19.16 \%)$ & & $119(31.73 \%)$ & \\
\hline & & & $46(21.20 \%)$ & $4(9.09 \%)$ & $115(34.74 \%)$ & $4(9.09 \%)$ \\
\hline $\begin{array}{l}\text { Table AI. } \\
\text { Descriptive statistics }\end{array}$ & $>65$ years & $105(16.50 \%)$ & $\begin{array}{l}16(6.13 \%) \\
15(6.91 \%)\end{array}$ & $1(2.27 \%)$ & $\begin{array}{l}89(23.73 \%) \\
88(26.59 \%)\end{array}$ & $1(2.27 \%)$ \\
\hline
\end{tabular}

Table AI.
Descriptive statistics 


\begin{tabular}{llll}
\hline Items & Loadings $(t$-value $)$ & Mean & SD \\
\hline
\end{tabular}

Emotions Laros and Steenkamp (2005); Smith and Bolton (2002); White and Yu (2005)

Positive Emotions (PEM)

$\alpha=0.959 ; \mathrm{CR}=0.959 ; \mathrm{AVE}=0.824$

Referring to the experience during the shopping journey, say which one of these emotions reflects how you felt

Delighted

Glad

$0.929(38.159)$

$0.931(36.275)$

$0.947(40.834)$

$0.895(35.838)$

$0.831(30.814)$

5.13

5.45

5.01

2.49

Happy

Excited

Pleased

$0.858(25.527)$

$0.958(27.650)$

$0.968(29.757)$

$0.898(23.080)$

0.654 (18.053)

$5.41 \quad 2.70$

$5.43 \quad 2.64$

$\alpha=0.935 ; \mathrm{CR}=0.941 ; \mathrm{AVE}=0.765$

Frustrated

Angry

Annoyed

Distressed

Bored

(2006): Sweeney an

$2.97 \quad 2.48$

$2.77 \quad 2.42$

$2.78 \quad 2.43$

$2.58 \quad 2.35$

PV Fandos et al. (2006); Moliner et al. (2005); Sánchez et al. (2006); Sweeney and Soutar (2001) $\alpha=0.890 ; C R=0.936 ; A V E=0.879$

FV

The Retailer $X$ provides services correct as a whole

$3.29 \quad 2.73$

The Retailer $X$ has a qualified salesforce, they know their job well

The Retailer $X$ provides correct quality-price ratio $\mathrm{SV}$

The Retailer $X$ has a positive social image

The Retailer $X$ has a good image for my friends and relatives

$\begin{array}{lll} & 6.59 & 1.95 \\ & & \\ 0.965(15.132) & 6.75 & 2.20 \\ & 6.14 & 2.14 \\ & 6.92 & 1.88 \\ & 6.54 & 2.06 \\ 0.926(23.491) & 6.71 & 2.10\end{array}$

The Retailer $X$ has a positive image for me, considering all the items specified above

$0.926(23.491)$

SATISFACTION (SAT) Bloemer and Odekerken-Schröder (2002); Oliver (1999) $\alpha=0.938 ; C R=0.941 ; A V E=0.800$

The Retailer $X$ confirms my expectations

$0.898(30.335)$

6.45

After shopping at the Retailer X, I am happy in my choice

After shopping at the Retailer X, I think I have made the right choice

$0.945(34.040)$

6.38

In general, I am satisfied with the Retailer $X$

$0.803(24.709)$

$0.925(33.728)$

5.54

2.33

6.40

Table AII.

Notes: Participants responded using a 11-point Likert scale: $0=$ completely disagree and $10=$ completely agree; $\alpha$ : Cronbach's alpha; CR: composite reliability; AVE: average variance extracted 
Table AIII.

Research shopping measurement (Question I)
RESEARCH SHOPPING BEHAVIOR (RSB)

Referring to the shopping journey, say which one of these sentences more closely reflects your buying behavior

I used just a single channel (physical store or the internet) during my shopping journey

I used physical store and the Internet during the shopping journey

$(\%)$

$\begin{array}{ll}\text { Items } & \text { Yes }\end{array}$

INFORMATION SOURCES (IS)

Referring to the shopping journey, say which of these sources you used for searching for information OFFLINE

Mobile phone manufacturer's stores (e.g. Apple Store)

14.78

85.22

Telecom stores (Movistar Store, Vodafone Store. . .)

76.26

23.74

Category-killers (e.g. FNAC, Media Markt. . .)

74.06

Department stores (e.g. El Corte Inglés)

76.89

Others (friends, relatives, catalogues. . .)

83.49

ONLINE

Mobile phone manufacturer's stores (e.g., Apple Online Store) $\quad 27.79 \quad 72.21$

Telecom stores (Movistar Online Store, Vodafone Online

Store...)

Category-killers (e.g. FNAC, Media Markt. . .)

40.88

Department stores (e.g. El Corte Inglés Online Store)

15.09

12.58

87.42

Others (social media, blogs, shopbots. . .)

SHOPPING PLACE (SP)

Say which one of these places you chose to purchase your mobile phone

\section{OFFLINE}

Mobile phone manufacturer's stores (e.g. Apple Store) 1.73

Telecom stores (Movistar Store, Vodafone Store. . .) $\quad 67.30$

98.27

32.70

Category-killers (e.g. FNAC, Media Markt...)

95.75

Department stores (e.g. El Corte Inglés)

93.08

Others (friends, relatives, thrift shop. . .)

92.92

ONLINE

Mobile phone manufacturer's stores (e.g. Apple Online Store) $\quad 1.57 \quad 98.43$

Table AIV.

Telecom stores (Movistar Online Store, Vodafone Online

88.99

Research shopping measurement

Store...)

11.01

Category-killers (e.g. FNAC, Media Markt. . .)

0.31

99.69

Department stores (e.g. El Corte Inglés Online Store)

0.31

99.69

Others (social media, eBay. . .) 


\begin{tabular}{lll}
\hline Item & Mean & SD \\
\hline
\end{tabular}

RESEARCH SHOPPING BEHAVIOR (RSB2)

Referring to the shopping journey, of this pair of sentences, say which one more closely reflects your buying behavior

"I searched for information and purchased the mobile phone using just a single channel

(physical store or the Internet)" and "I searched for information and purchased the mobile phone using multiple channels (physical store and the internet)"

Table AV.

Research shopping behavior (Question

WEBROOMING VERSUS SHOWROOMING (RSB3)

Referring to the shopping journey, say which one of these sentences more closely reflects your buying behavior

Searching for information online and then buying in a physical store (webrooming behavior)

Table AVI.

Webrooming and showrooming measurement

\begin{tabular}{lcccc}
\hline Items & NEM & PEM & PV & SAT \\
\hline NEM & $\mathbf{0 . 8 7 5}$ & $(-0.337,-0.069)$ & $(-0.364,-0.132)$ & $(-0.424,-0.088)$ \\
PEM & $-0.203^{* * *}$ & $\mathbf{0 . 9 0 8}$ & $(0.397,0.697)$ & $(0.437,0.599)$ \\
PV & $-0.248^{* * * *}$ & $0.547 * * *$ & $\mathbf{0 . 9 3 8}$ & $(0.779,0.969)$ \\
SAT & $-0.256^{* * * *}$ & $0.513^{* * * *}$ & $0.868^{* * * *}$ & $\mathbf{0 . 8 9 5}$
\end{tabular}

Notes: The data in bold and on the diagonal are the AVE of each concept. The data below the diagonal correspond to the squared correlations between pairs of constructs. The confidence intervals of all the correlations between the concepts are above the diagonal (italics). There is discriminant validity, given that the confidence intervals of all the correlations between the concepts analyzed did not contain the unit value and its squared value did not exceed the AVE of the measurement scales considered. ${ }^{*} p<0.10$; $* * p<0.05$; $* * * p<0.001$

Table AVII. Discriminant validity 


\begin{tabular}{llcr} 
& Constraints & Chi-square & Probability \\
\cline { 2 - 4 } Table AVIII. & $H 1 a: \mathrm{EMP} \rightarrow \mathrm{VP}$ & 1.699 & 0.025 \\
Multigroup & $H 1 b: \mathrm{EMN} \rightarrow \mathrm{VP}$ & 0.350 & 0.145 \\
analysis - research & $H 2 a: \mathrm{EMP} \rightarrow \mathrm{SAT}$ & 1.154 & 0.045 \\
shopping versus one- & $H 2 b: \mathrm{EMN} \rightarrow \mathrm{SAT}$ & 0.255 & 0.150 \\
stop shopping & $H 3: \mathrm{VP} \rightarrow \mathrm{SAT}$ & 2.670 & 0.067 \\
\hline
\end{tabular}

Table AIX. Multigroup analysis webrooming versus showrooming

\begin{tabular}{lcc}
\hline Constraints & Chi-square & Probability \\
\hline$H 4 a: \mathrm{EMP} \rightarrow \mathrm{VP}$ & 0.199 & 0.122 \\
$H 4 b: \mathrm{EMN} \rightarrow \mathrm{VP}$ & 5.960 & 0.032 \\
$H 5 a: \mathrm{EMP} \rightarrow \mathrm{SAT}$ & 0.607 & 0.115 \\
$H 5 b: \mathrm{EMN} \rightarrow \mathrm{SAT}$ & 3.021 & 0.082 \\
$H 6: \mathrm{VP} \rightarrow \mathrm{SAT}$ & 1.697 & 0.136 \\
\hline
\end{tabular}




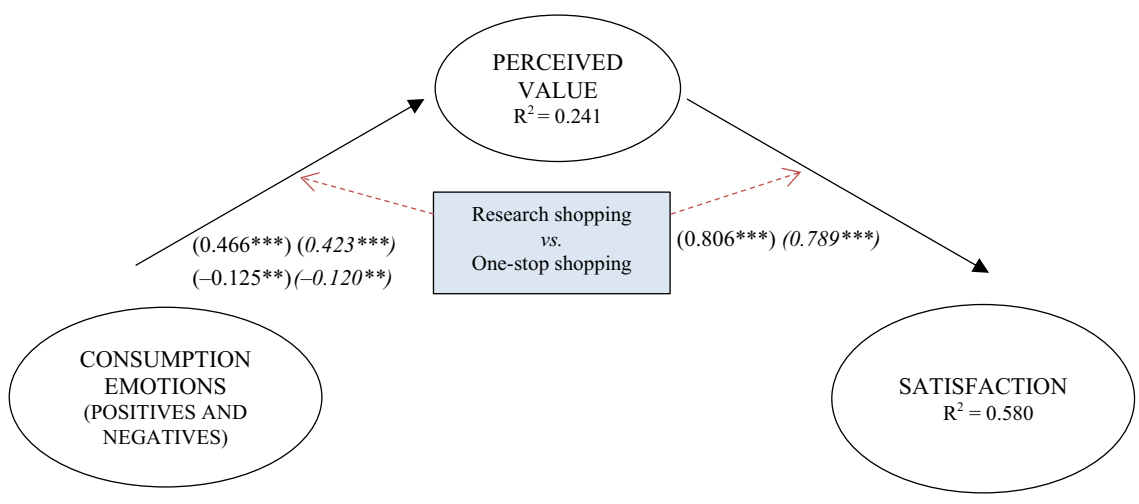

Notes: ${ }^{*} p<0.10 ;{ }^{* *} p<0.05 ;{ }^{* * *} p<0.001$

Figure A1. Full mediation model results (research shopping versus onestop shopping)

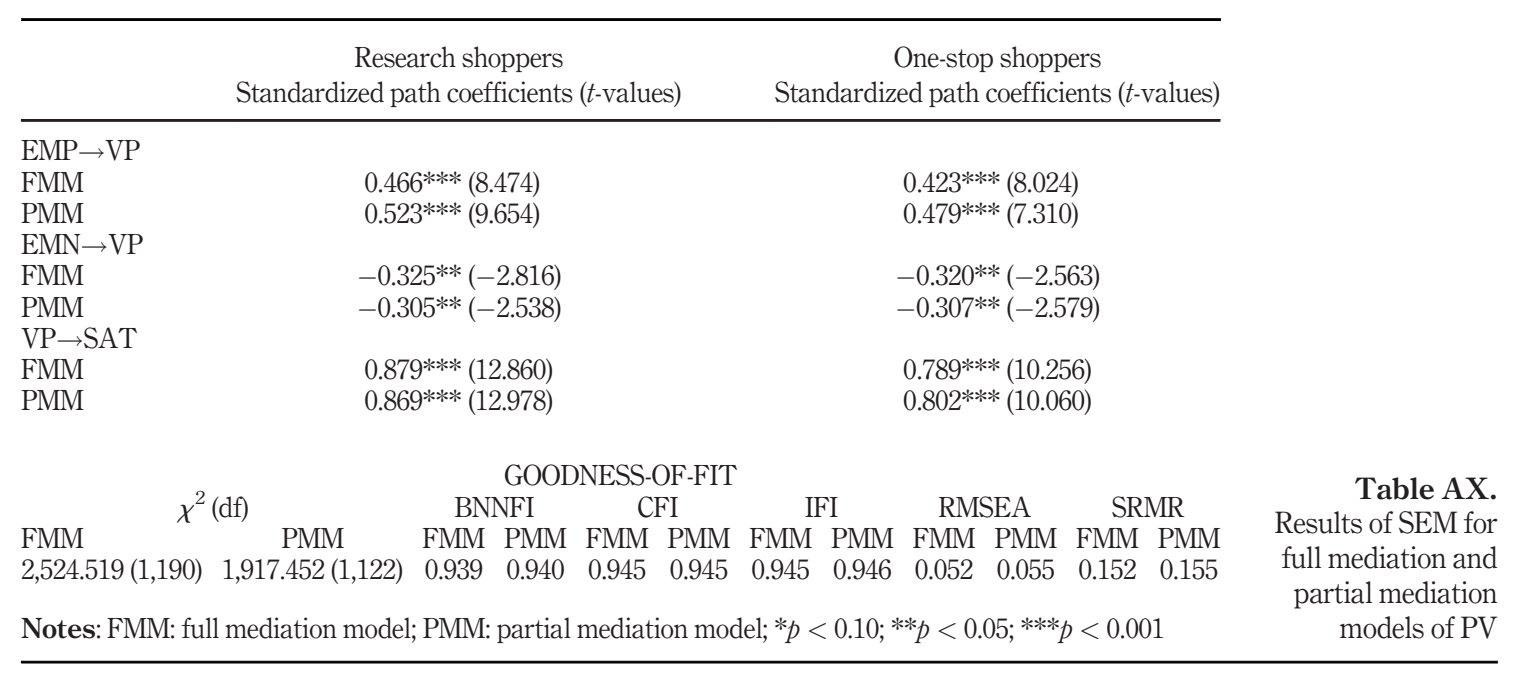




\section{Figure A2.}

Full mediation model results (webrooming versus showrooming)

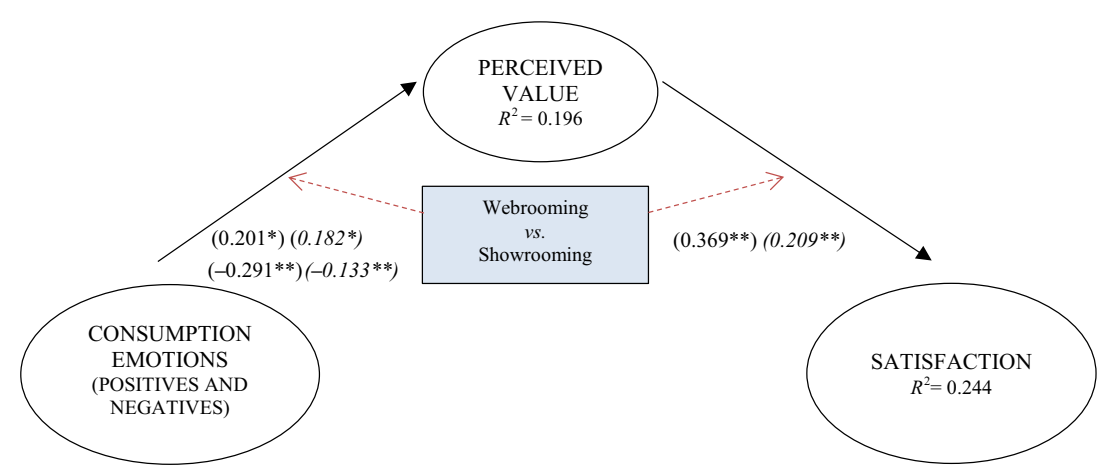

Notes: ${ }^{*} p<0.10 ; * * p<0.05 ; * * * p<0.001$

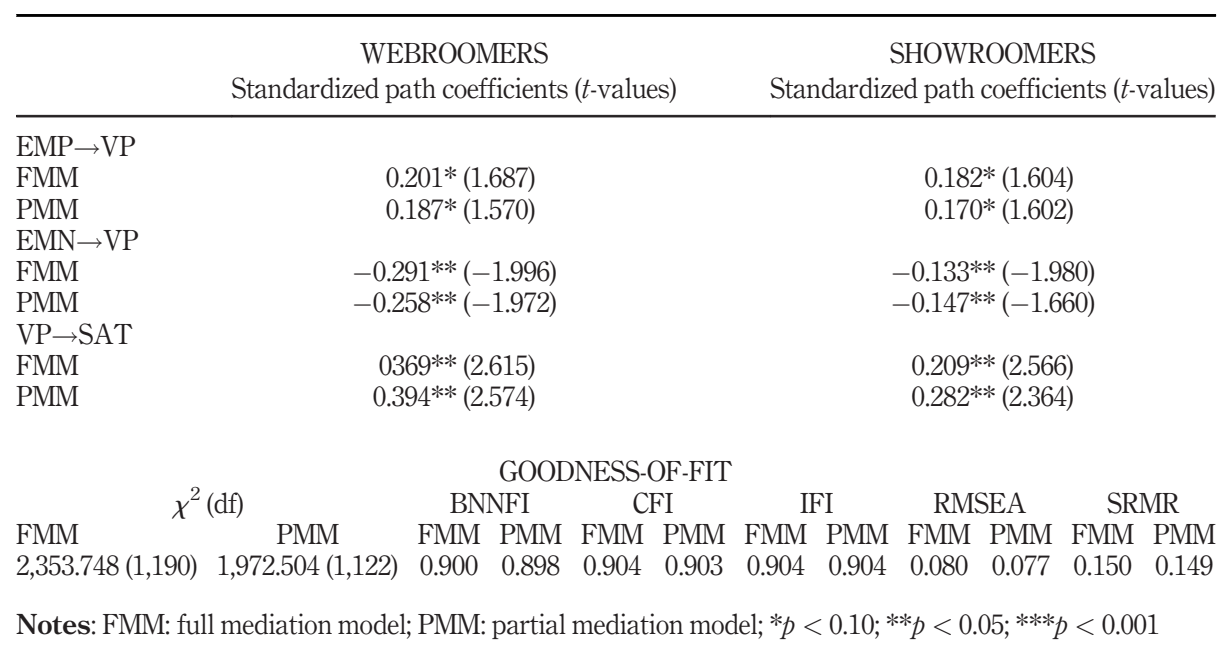

Table AXI.

Results of SEM for full mediation and partial mediation models of PV $\begin{array}{lccccccccccc}\text { FMM } & \text { PMM } & \text { FMM } & \text { PMM } & \text { FMM } & \text { PMM } & \text { FMM } & \text { PMM } & \text { FMM } & \text { PMM } & \text { FMM } & \text { PMM } \\ 2,353.748(1,190) & 1,972.504(1,122) & 0.900 & 0.898 & 0.904 & 0.903 & 0.904 & 0.904 & 0.080 & 0.077 & 0.150 & 0.149\end{array}$

Notes: FMM: full mediation model; PMM: partial mediation model; $* p<0.10 ; * * p<0.05 ; * * * p<0.001$

Nuria Viejo-Fernández can be contacted at: nuriavjf@uniovi.es

For instructions on how to order reprints of this article, please visit our website: 